\title{
Effect of salt marsh inundation on estuarine particulate organic matter characteristics
}

\author{
M. A. Hemminga ${ }^{1}$, V. A. Klap ${ }^{1}$, J. van Soelen ${ }^{1}$, J. J. Boon ${ }^{2}$ \\ ${ }^{1}$ Netherlands Institute of Ecology - Centre for Estuarine and Coastal Ecology, Vierstraat 28, 4401 EA Yerseke, \\ The Netherlands \\ ${ }^{2}$ FOM Institute for Atomic and Molecular Physics, Kruislaan 407, 1098 SJ Amsterdam, The Netherlands
}

\begin{abstract}
During tidal inundation, exchange of particulate organic matter POM between salt marshes and tidal water may occur. This may result in changes in the seston-POM characteristics of the water. We investigated wheter such changes were found after inundation of Saeftinge, a salt marsh in the Westerschelde estuary (SW Netherlands). Seston was collected from a tidal creek of the marsh during 22 flood-ebb tide cycles. The characteristics of the flood and ebb seston samples were assessed by microbial bioassays, pyrolysis-mass spectrometry, and the determination of chlorophyll $(a+b)$. There was a very strong agreement between the seasonal pattern in biodegradability and the seasonal pattern in chemical signature of the seston-POM. During autumn and winter, the degradability of sestonPOM in the Westerschelde was relatively low. Neither the degradability nor the chemical characteristics of the POM showed much variation in this period. The enrichment of the POM-pool with phytoplankton appeared to be the major factor increasing the biodegradability and causing the changes in chemical characteristics of seston-POM in the Westerschelde in spring and summer. Only during a 2 mo period in summer did salt marsh inundation result in consistent differences in POM characteristics between flood and ebb: compared to the POM in the flood water, the POM leaving the marsh during the ebb was more refractory. In other periods, salt marsh inundation hardly affected biodegradability and chemical composition of seston-POM. This is considered an indication that the large estuarine salt marsh of Saeftinge is an irrelevant factor in determining the nature of POM in the estuary. The lack of differences between flood and ebb tide seston-POM also suggests that export of vascular plant detritus from this marsh, at least during moderate weather conditions, is insignificant.
\end{abstract}

\section{INTRODUCTION}

Suspended matter in estuaries originates both from external and internal sources. Material from land runoff and marine particulate matter imported from the sea constitute that from external sources. Autochtonous primary production of pelagic and benthic algae and erosion of sediments are major internal sources. Estuarine salt marshes may function as internal sources of particulate matter as well. During tidal inundation, processes such as surface erosion and release of organic particles from vegetation may result in the addition of particles from the salt marsh to the water; however, the water may also lose particles by trapping, sedimentation and biological uptake. Studies on the quantification of the net fluxes of particulate matter between salt marshes and adjacent water have yielded much information on the complexity of material efflux from salt marshes differing in geomorphology, tidal exposure and vegetation cover. However, the ecological relevance of fluxes of particulate organic matter not only depends on the magnitude of these fluxes, but also on the bioavailability of the organic material. Since the pioneering studies of Teal (1962) and Odum \& de la Cruz (1967), it has generally been assumed that the ebb water leaving the Spartina alterniflora dominated salt marshes of the North American Atlantic and Gulf coasts is enriched with material from this plant. Consequently, studies on the role of carbon originating from salt marshes have been strongly focused on $S$. alterniflora. The bioavailability of particulate material derived from $S$. alterniflora has been tested in feeding experiments with various coastal marine organisms (e.g. Stuart et al. 1985, Newell \& 


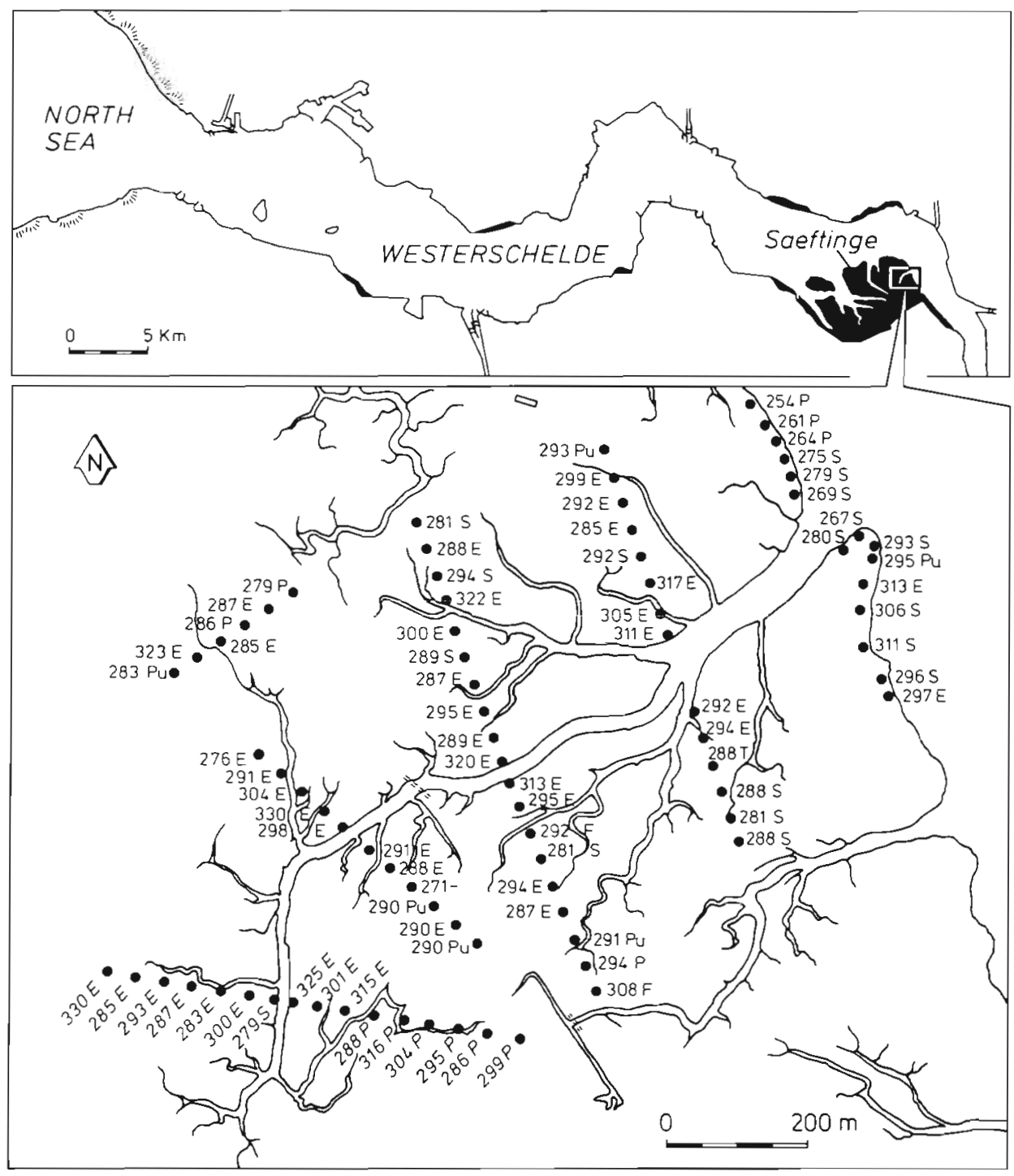

Fig. 1. Westerschelde estuary in the SW Netherlands with the Saeftinge salt marsh and the tidal marsh creek sampled in this study. In the drainage area of the creek the level of the marsh surface in a series of transects is indicated in cm above Dutch Ordnance Level (NAP). The locally dominating halophyte is indicated: E: Elymus pycnanthus; S: Scirpus maritimus; P: Phragmites australis; Pu: Puccinellia maritima; F: Festuca rubra

Langdon 1986, Kreeger et al. 1988, D'Avanzo \& Valiela 1990). Stable isotopes have been used to elucidate the contribution of salt marsh cord grass as a source of organic matter to intertidal and subtidal fauna (e.g. Hughes \& Sherr 1983, Peterson et al. 1986, Peterson \& Howarth 1987, Deegan et al. 1990, Sullivan \& Moncreiff 1990). Studies on the ecological relevance of tide-driven carbon fluxes in salt marsh-coastal water systems in Western Europe need another approach. The species assemblage of these marshes usually consists of species with C-3 and C-4 photosynthetic pathways. This makes a carbon isotopic approach for investigating halophyte-carbon efflux and assimilation by coastal consumers less feasible. Moreover, the vegeta- tion of these marshes lacks species which are growing low in the intertidal zone (Beeftink 1977). The contribution of salt marsh halophytes to carbon efflux from West European marshes therefore is not self-evident. In a recent study on seston in ebb tide water flowing from a coastal salt marsh, we could not find evidence for input of material from vascular plants to the POMpool of the water (Hemminga et al. 1992). The sestonPOM characteristics, however, were consistently shifted after salt marsh inundation. The investigated salt marsh was of the beach plain type (Beeftink 1977). with one tidal inlet through which the system is drained, and dunes shielding most of the marsh. In the present study we focused on a more 'open', estuarine 
tidal marsh. To investigate if inundation resulted in ecologically relevant changes in the seston-POM characteristics of the water, a bioassay and chemical analyses were applied. The biodegradability of the material was assessed by determining microbial respiratory activity on the seston. Further, pyrolysis-mass spectrometry and chlorophyll $(a+b)$ analyses were applied to the samples.

\section{METHODS}

Study area. The Westerschelde estuary (SW Netherlands) is the final transect of the Schelde river before it debouches in the North Sea. The largest salt marsh in the estuary is Saeftinge (2800 ha; Fig. 1). The annual mean tidal range in the part of the estuary where Saeftinge is situated is approximately $4.8 \mathrm{~m}$; mean salinity at high tide is about $10 \%$. Seston samples were taken in the mouth of a tidal creek on the eastern side of Saeftinge. Dominant halophyte species in the drainage area of this creek are Elymus pycnanthus, Scirpus maritimus, Phragmites australis and Puccinellia maritima. The marsh level in the drainage area of the creek is between +254 and $+330 \mathrm{~cm}$ NAP (Dutch Ordnance Level, corresponding approximately with mean sea level) (Fig. 1). The water level in the creek starts to rise only approximately $3 \mathrm{~h}$ before HW. because its bed is situated above mean low water. The duration of the subsequent emptying of the creek takes 3 to $4 \mathrm{~h}$. Current velocities peak during ebb tide (Fig. 2).

Sampling. Water samples were collected during 21 tidal cycles throughout 1990 and 1 cycle early in 1991. Incoming water was sampled $2.5,1.5$ and $0.5 \mathrm{~h}$ prior to
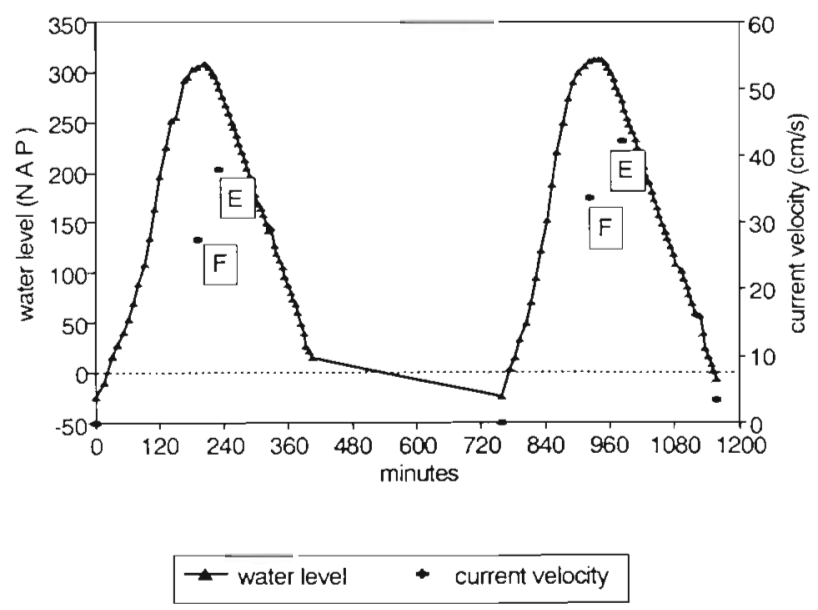

Fig. 2. Example of the tidal characteristics measured in the salt marsh creek which was sampled in this study. Indicated are the water levels and peak flood and ebb tide current velocities $(F, E)$ during 2 successive flood-ebb tide cycles predicted high tide. The sampling moments thus covered the major part of the inflow period. Samples of the ebb flow were taken 2,3 and $3.5 \mathrm{~h}$ after the turn of the tide. Ebb tide samples were taken during the second part of the outflow period, as it was expected that a possible shift in seston characteristics due to salt marsh inundation would be most conspicuous in this period. At each sampling time, 100 to $125 \mathrm{l}$ was taken from the water surface, and 1 l portions were filtered over Whatman GF/C filters for determination of seston, POC and chlorophyll $(a+b)[\operatorname{chl}(a+b)]$. The remaining samples of each tide were pooled and the particulate material in the water was obtained by continuous flow centrifugation at $13000 \times g\left(200 \mathrm{l} \mathrm{h}^{-1}\right)$, using a shipboard Sharples Super Centrifuge (type AS 16). The seston samples obtained were immediately frozen. and afterwards lyophilized.

Analyses. Seston and POC on the Whatman GF/C filters were determined with a Carlo Erba NA1500 carbon and nitrogen analyzer. The filters were fumed with $\mathrm{HCl}$ prior to analysis. Carbon in the seston collected by continuous centrifugation was determined with the same apparatus. Chl $(a+b)$ in seston filtered on Whatman GF/C filters was extracted with $90 \%$ acetone, and determined by HPLC (Waters Associates).

To assess the biodegradability of the seston-POM, aliquots of the lyophilized seston samples (100 mg) were mixed with $2 \mathrm{ml}$ of a microbial inoculum (see below). Subsequently, the mixture was incubated in capped $310 \mathrm{ml}$ glass bottles in the dark at $15^{\circ} \mathrm{C}$. After 7,14 and $21 \mathrm{~d}$, the $\mathrm{CO}_{2}$ evolution in the bottles was measured by gas chromatography. The data were corrected for $\mathrm{CO}_{2}$ background values.

The inocula used in the assay were of 2 different types, a natural estuarine multi-species assemblage and a single estuarine bacterial species respectively. Using the estuarine assemblage has the potential disadvantage that differences between the samples may be obscured if a relative high or low metabolic activity of one group of organisms is compensated by the activity of others. With one bacterial species the risk is that, of the array of organic compounds in the seston, only a limited part would be attacked, as degradation of organic substrates is restricted by the metabolic capacities of the particular species used; this would limit the assessment of biodegradability of the POM as a whole. By applying both types of inocula, the potential disadvantage connected to each of them is met.

The multi-species inoculum was obtained by filtering Westerschelde water collected near the study site through Millipore filters (pore diameter $1.2 \mu \mathrm{m}$ ). The single species used for the second type of inoculum (a Gram-negative species of the Spirilla type) was isolated from estuarine water by repeated transfer of single colonies to a mineral medium with a salinity of 
$14 \%$, enriched with yeast extract $\left(10 \mathrm{mg} \mathrm{l}^{-1}\right)$, and solidified with $2 \%$ agar. In the medium of the last culture step, yeast and agar were deleted and glucose $1500 \mathrm{mg}$ $\mathrm{l}^{-1}$ ) was added. After a period of $4 \mathrm{~d}$, inocula of the final culture were mixed with seston samples. In the biodegradability assay with the single bacterial species, the lyophilized seston samples were sterilized by gammairradiation (50 kGy), prior to addition of the bacterial inoculum.

Chemical characterization of the seston was carried out by pyrolysis mass spectrometry (PyMS; for details see e.g. Boon 1989). Prior to analysis the lyophilized seston samples were desalted by 3 cycles of washing with deionized water followed by centrifugation. Insource pyrolysis was performed by pipetting aliquots of the resuspended seston on a $\mathrm{Rh} / \mathrm{Pt}$ sample wire. The wire was subsequently heated resistively to $800^{\circ} \mathrm{C}$ in $1 \mathrm{~min}$ in the ionization chamber of the mass spectrometer. As a result the organic matter in the sample was degraded into smaller molecules. These molecules were ionized by low voltage Electron Impact $(16 \mathrm{eV})$. The resulting ions were measured with a JEOLDX-303 double-focusing (E/B) mass spectrometer equipped with a JEOL 5000 data system. All seston samples were analyzed in triplicate. The seston samples consisted of a mixture of many different components. Each individual component has its own mass spectrum and in the case of a multi-component mixture, an integrated spectrum of the whole mixture was obtained. The set of MS-spectra was analyzed by factor discriminant analysis (Hoogerbrugge 1983, Windig et al. 1983). In this procedure the variation in the set of spectra is described by discriminants, which can be translated into information about the chemical composition. The successive discriminants each describe part of this variation. Previous applications of this procedure for the chemical characterization of seston, of both estuarine and freshwater origin, can be found in Eisma et al. (1985), Boers \& Boon (1988) and Hernminga et al. (1992).

Statistical differences between flood and ebb series were tested by ANOVA, on log-transformed data. Pearson correlation coefficients were determined to assess the correlation between various seston characteristics

\section{RESULTS}

HW levels on the sampling days varied between +223 and $+388 \mathrm{~cm}$ NAP (Fig. 3). The drainage area of the creek covered with vegetation is situated between +254 and $+330 \mathrm{~cm}$ NAP (Fig. 1); thus the inundation percentage varied between 0 and $100 \%$. The majority of samples was taken during tidal cycles when HW lev-

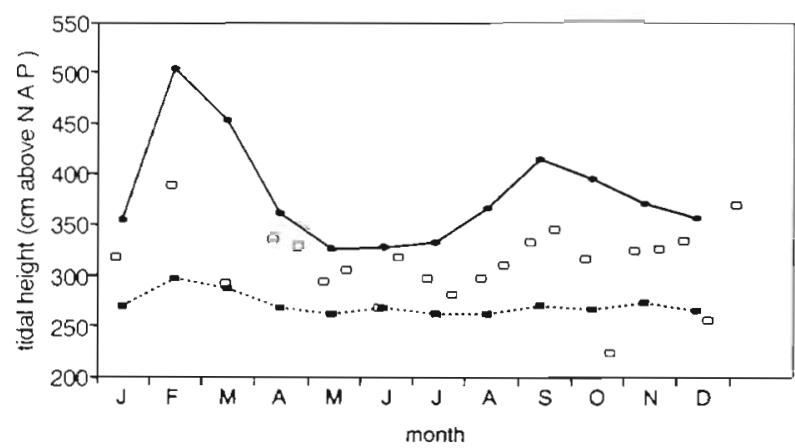

-. monthly average $\leftarrow$ highest monthly HW $\square$ sampling dates

Fig. 3. High water levels in the Westerschelde estuary near Saeftinge during the sampling period in 1990 and high water levels on the 22 sampling dates

els were well above the monthly average HW. Consequently, flooding of substantial parts of the vegetated area nearly always occurred on the sampling dates.

The POC content of the seston in the samples taken during flood and ebb is shown in Fig. 4. If the average values of the 3 sample taken during the flood $(2.5,1.5$ and $0.5 \mathrm{~h}$ before $\mathrm{HW}$ ) are compared to those of the first 2 samples during the ebb ( 2 and $3 \mathrm{~h}$ after HW), the flood values are higher than the ebb values nearly throughout the year. The last ebb sample $(3.5 \mathrm{~h}$ after HW), however, which was taken at the end of the water outflow from the creek, often had a high POC content. If these samples are included, the average POC values of the ebb phase increase and regularly reach values higher than the average POC values of the flood phase. This implies that the ebb seston-POM

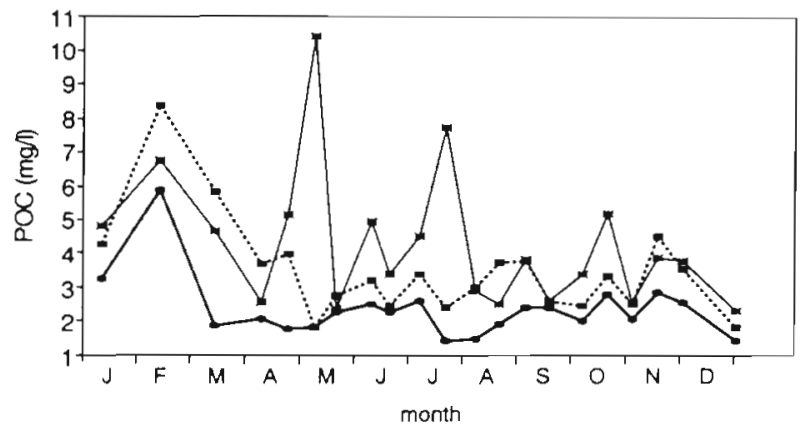

.. flood tide $\rightarrow$ ebb tide $t(1+2)$ ebo tide $t(1+2+3)$

Fig. 4. POC contents of seston samples collected in the salt marsh creek. Data of the flood tide curve are the means of samples taken $2.5,1.5$ and $0.5 \mathrm{~h}$ prior to predicted high tide The ebb tide $(1+2)$ curve is based on the means of samples taken 2 and $3 \mathrm{~h}$ after the turn of the tide; the ebb tide $(1+2+3)$ curve on samples taken 2,3 and $3.5 \mathrm{~h}$ after the turn of the tide 
Table 1. Matrix of Pearson correlation coefficients, determined for various seston-POM characteristics. $\mathrm{CO}_{2} \mathrm{MIX}$ : biodegradability as measured with a microbial assemblage (14 d incubations); $\mathrm{CO}_{2}$ SING: biodegradability as measured with a single bacterial species (14 d incubations); D1. scores of the first discriminant determined after PyMS analysis; Chl/POC: chlorophyll to POC ratios. For further details, see text

\begin{tabular}{|lcccr|}
\hline & $\mathrm{CO}_{2} \mathrm{MIX}$ & $\mathrm{CO}_{2} \mathrm{SING}$ & $\mathrm{D} 1$ & $\mathrm{Chl} / \mathrm{POC}$ \\
\hline $\mathrm{CO}_{2} \mathrm{MIX}$ & \multirow{2}{*}{1.000} & 0.984 & -0.976 & 0.949 \\
$\mathrm{CO}_{2} \mathrm{SING}$ & & 1.000 & -0.953 & 0.927 \\
$\mathrm{D} 1$ & & & 1.000 & -0.937 \\
$\mathrm{Chl} / \mathrm{POC}$ & & & & 1.000 \\
\hline
\end{tabular}

which was used for further characterization is strongly influenced by the material in the water during the last sampling.

The assays for detecting differences in the biodegradability of the samples showed that $\mathrm{CO}_{2}$ levels in the incubation bottles gradually increased during the period that the seston was incubated with the microbial inoculum. The overall pattern of differences in $\mathrm{CO}_{2}$ evolution between the samples, however, remained similar. We therefore present only one time series ( $14 \mathrm{~d}$ incubation). Fig. 5 shows that the pattern of $\mathrm{CO}_{2}$ production in the incubations with the estuarine microbial assemblage is nearly identical to that obtained with the single bacterial species (Pearson correlation coefficient: 0.984 ; Table 1). The $\mathrm{CO}_{2}$ production ranged from ca 50 to $350 \mu \mathrm{mol} \mathrm{CO} \mathrm{mmol}^{-1}$ seston $\mathrm{C}$, i.e. between 5 and $35 \%$ of the organic matter in the seston was mineralized after $14 \mathrm{~d}$. The results further show that there are clear seasonal differences in the degradability of estuarine POM: it is low in autumn, winter, and early spring, higher in late spring and in summer, and shows a very conspicuous peak on 23 May. For statistical analysis (ANOVA) of the data, 2 time intervals were distinguished: an autumn/winter period (21 September to 21 March), and a spring/summer period (21 March to 21 September). The overall difference between flood tide and ebb tide series in the autumn/winter period was not significant for either the experiment with the microbial mixture or the experiment with the single bacterial species $(p=0.135$ and $p=0.802$ respectively). In both assays, however, the flood and ebb tide series differed significantly in the spring/summer period (assay with microbial mixture: $p=0.024$; with single bacterial species: $p=0.017$ ) Visual inspection of the curves of both assays shows that in the spring/summer period consistent differences between flood and ebb tide series exist, from 11 June to 8 August. In this period, the POM in the flood tide samples appears to have a higher degradability than the ebb tide samples.

Pyrolysis mass spectrometry was carried out to in-
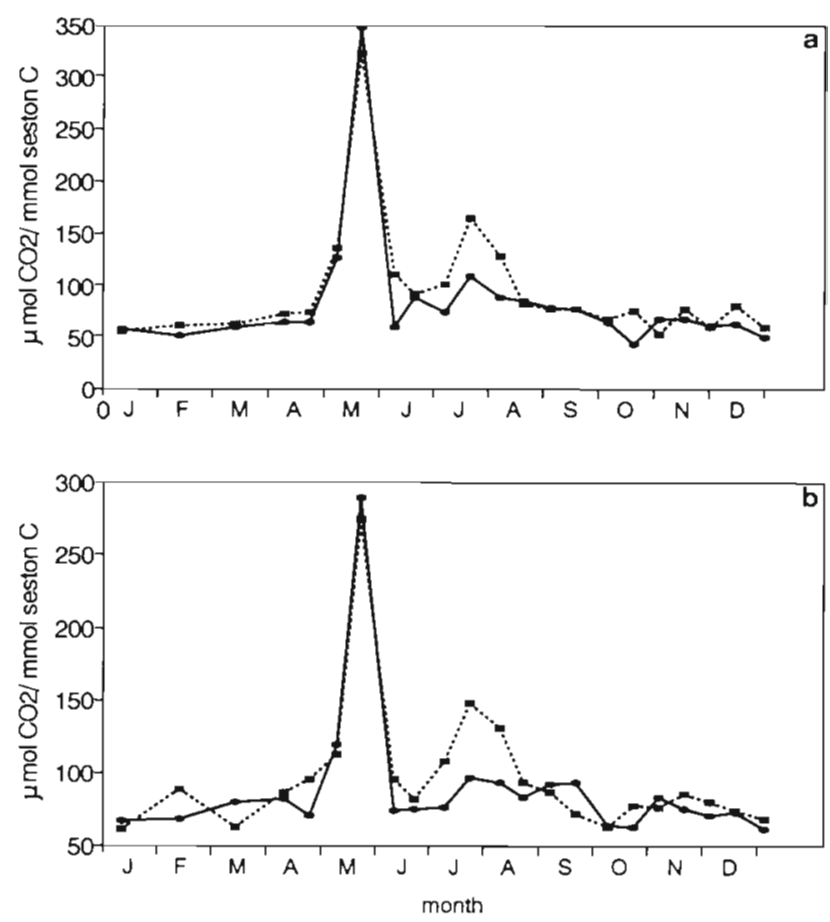

$\cdots$ flood tide $\rightarrow-$ ebb tide

Fig. 5. $\mathrm{CO}_{2}$ production of (a) an estuarine microbial assemblage and (b) a single estuarine bacterial species on seston samples collected during flood and ebb tides in the salt marsh creek

vestigate if the pattern of biodegradability coincides with chemical changes in the seston POM. A detailed presentation of the PyMS data is outside the scope of this paper, and will be published elsewhere. For the purpose of this paper, the set of PyMS spectra was subjected to factor discriminant analysis to describe the variation in the spectra. In this procedure, every individual spectrum is redefined as a sum of discriminant scores, allowing a comparison of flood and ebb series. The first discriminant (D1) describes $28.2 \%$ of the total variation in the PyMS spectra. Successive discriminants describe a far smaller part of the variation (D2: $1.7 \%$ D3: $2.5 \%$ ) and will not be considered. Fig. 6 shows the D1 scores of the flood and ebb tide samples. Increasingly negative values in this figure coincide with a more pronounced lipid character of the seston (especially C14 and C16 saturated fatty acids and phytadiene). The form of the curves shows a striking similarity with those of the biodegradability assays (Fig. 5). This similarity is expressed by very high correlation coefficients (Table 1). Again the conspicuous peak on 23 May appears, and the consistent difference between flood and ebb tide samples between 11 June and 8 August. The PyMS data thus indicate that differences in the biodegradability of POM are based on 


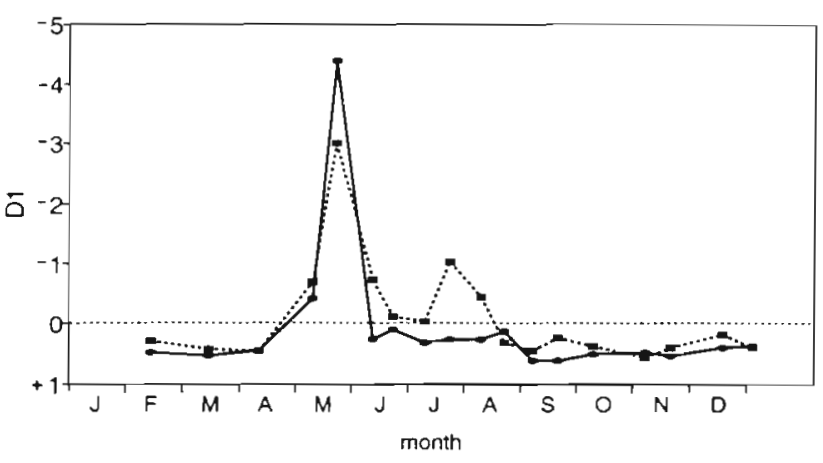

\section{... flood tide $\rightarrow$ ebb tide}

Fig. 6. PyMS analysis of seston samples: scores of the first discriminant. Seston samples were collected during flood and ebb tides in the salt marsh creek

changes in the chemical composition of the samples. The PyMS data furthermore indicate, in agreement with the data on biodegradability, that during the larger part of the year inundation of Saeftinge does not influence the characteristics of seston-POM very much.

Further insight in changes in POM characteristics is obtained by plotting the chl $(a+b)$ to POC ratio of the seston samples (Fig. 7). The resulting curves are very similar to the results describing biodegradability and chemical composition (Table 1). This finding indicates that the changing pattern of seston-POM characteristics is strongly determined by the varying contribution of chlorophyll-containing particles to the POM pool. Most probably, these particles were microscopic phytoplankton cells: in the period of high chl/POC ratios (May-July), macroscopic green fragments from other primary producers, i.e macro-algae or vascular macrophytes, generally were not visible on the POM-filters.

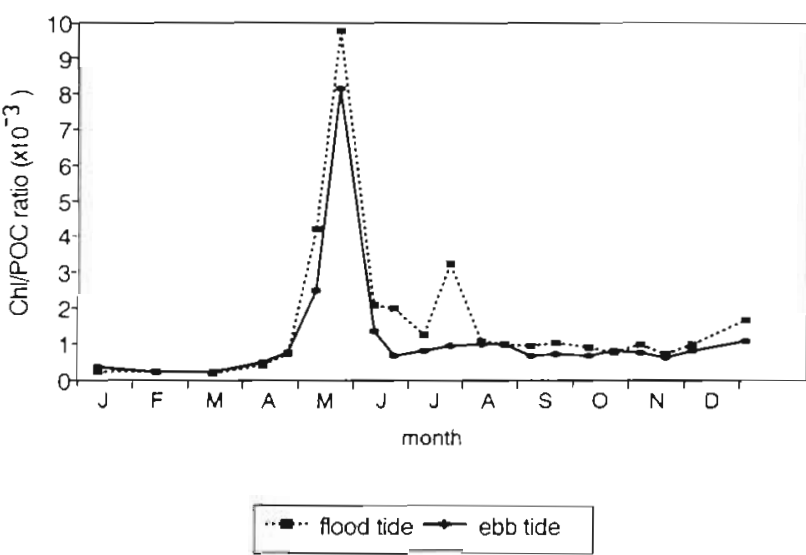

Fig. $7 \mathrm{Chl}(a+b)$ to POC ratios in seston samples collected during flood tide and ebb tide in the salt marsh creek

\section{DISCUSSION}

\section{Seasonal changes in POM characteristics}

The curves of $\mathrm{CO}_{2}$ production and of the discriminant scores show that the microbial degradability and the chemical composition of estuarine seston is subject to conspicuous seasonal changes. Moreover, the remarkable agreement between degradability and chemical signature clearly indicates that changes in degradability are primarily determined by chemical characteristics and not by other factors such as particle size (cf. e.g. Hargrave 1972). The similarity in results found with such widely different methodologies as a microbial biodegradability assay and PyMS can be a useful feature for other studies of estuarine seston.

The period May to the beginning of August excepted, the D1 scores show iitile temporal variation. Apparently, the seston POM in the estuary has a rather stable chemical composition during the largest part of the year; this composition is only conspicuously changed during the growing season of phytoplankton, when the seston is enriched with algal cells (see below). The relatively low microbial $\mathrm{CO}_{2}$ production on POM samples obtained in the first and the last part of the year indicates that the organic matter in these periods is made up of refractory compounds. This conclusion is supported by the PyMS data: the individual mass spectra of the samples (not shown) point to the presence of lignin-derived compounds, degraded polysaccharides and fragmented long aliphatic molecules; these compounds are suggestive of highly decomposed organic material. Apparently, the POM in the estuarine water consists of aged organic materia $\rfloor$ most of the year. An obvious component may be allochtonous organic material from the river drainage basin which has lost its degradable compounds during transport to the estuary (cf. Van Es \& Laane 1982, Laane et al. 1987).

The dominant factor influencing the seasonal changes in degradability and chemical composition of POM in the Westerschelde apparently is the relative enrichment of the POM with phytoplankton. The stable, relatively refractory character of the sestonPOM changes dramatically when chl/POC ratios increase. Chlorophyll levels in the estuarine (flood tide) water peak on 23 May and 23 July, coinciding with high chl/POC ratios. A number of studies have shown that carbon to chlorophyll ratios of phytoplankton range from about 20 to greater than 100 (e.g. De Jonge 1980 and references therein, Hewes et al. 1990). Assuming a carbon to chlorophyll ratio of 50, the phytoplankton C contribution to the total seston-POC pool would rise from a low value of $1 \%$ in January to peak 


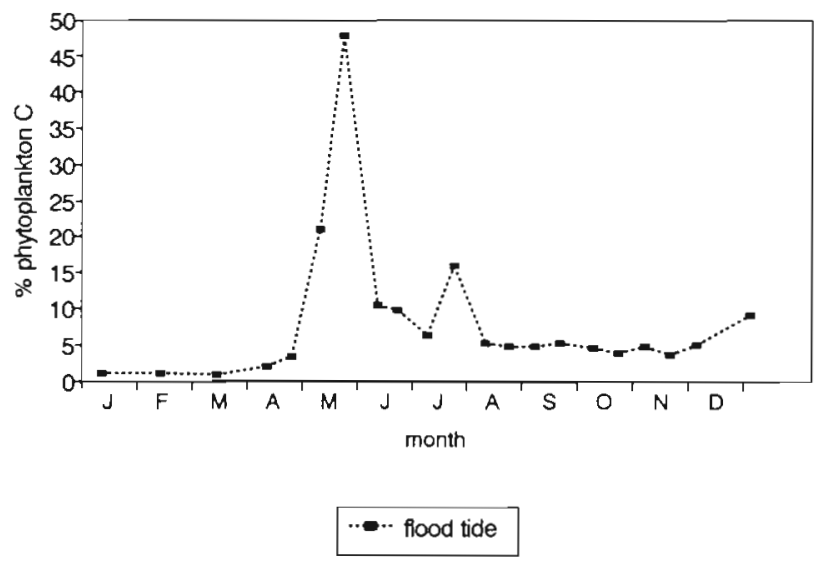

Fig. 8. Estimated phytoplankton carbon contribution to total seston-POC in the Westerschelde near Saeftinge. Percentages calculated using a carbon to chlorophyll ratio of 50 in the phytoplankton cells

values of 48 and $16 \%$ on 23 May and 23 July, respectively (Fig. 8). This phytoplankton may be of local origin. Studies on planktonic primary productivity in the Westerschelde show that near Saeftinge productivity strongly increases from April onwards, reaching peak values in June/July ( 1 to $2 \mathrm{~g} \mathrm{C} \mathrm{m}^{-2} \mathrm{~d}^{-1}$ ); a discrete, lower, second production peak early in August was found in 1989, but not in 1991 (J. Kromkamp pers. comm.). The enrichment of the POM with phytoplankton strongly increased its degradability, a finding which is in agreement with other studies showing that the degradability of estuarine POM increases with higher chlorophyll levels (Van Es \& Laane 1982, Hargrave \& Phillips 1989)

\section{Salt marsh inundation and POM characteristics}

Only during a short period of the year, 11 June to 8 August, did inundation of Saeftinge result in consistent differences in the microbial degradability and chemical characteristics between the flood period and ebb period POM samples. The POM leaving the marsh during the ebb was, on a carbon weight basis, more refractory than the flood tide POM. One reason for this phenomenon may be found in the relatively large change in the chlorophyll to POC ratio during salt marsh inundation in this period. The average chlorophyll levels in the flood tide water were 7 to $30 \%$ higher than in the ebb tide water in this period (results not shown), whereas the average POC content in ebb tide water was relatively high compared to flood tide levels (Fig. 4). It is unclear, however, why the consistent shift in seston characteristics was limited to this specific period. This period excepted, inundation of Saeftinge seemed hardly to affect the microbial de- gradability and the chemical composition of POM in the inundating water. This suggests that exchange of particulate organic matter during inundation is limited, and, consequently, that the export of halophyte detritus as seston particles from the marsh also is limited. This tentative conclusion is in agreement with earlier investigations in a coastal salt marsh south of the Westerschelde estuary (Het Zwin) which yielded no evidence for an increase in halophyte-derived lignin compounds in water leaving the area during ebb (Hemminga et al. 1992). Thus, insignificant efflux of halophyte-derived seston POM from western European salt marshes may be more the rule than the exception. It is uncertain to what extent our findings on this point contrast with the situation in the Spartina alterniflora-dominated salt marshes of North America. As mentioned in the introduction, $S$. alterniflora-derived material generally is considered to be a source of POC for the tidal water. Indeed, detrital particles of $S$. alterniflora have been identified in salt marsh creeks (Odum \& de la Cruz, 1967, Roman \& Daiber 1989) and in water adjacent to salt marshes (Cranford et al. 1987). In other studies, however, the contribution of $S$. alterniflora particles to seston-POM in a tidal creek was apparently absent (Haines 1976), or it was evident from budget calculations that primary production within the creeks and not efflux from the vegetated marsh could account for by far the largest part of the tidal carbon export (Dame et al. 1991). Studies of the specific sources of POM in tidal water flowing from these $S$. alterniflora-dominated marshes therefore would be interesting.

An assessment of the exchange of POM and, more specifically, the export of halophyte-derived organic material from a given salt marsh is complicated by several factors. In the first place, heavy rainshowers and storms may lead to the export of large pulses of coarse and small particulate organic material from the salt marsh (Chalmers et al. 1985, Wolaver \& Spurrier 1989, Roman \& Daiber 1989). Sampling during these episodic events in the tidal creeks of Saeftinge has been beyond our capabilities so far. Secondly, large marsh systems such as Saeftinge may be composed of subsystems having different properties with respect to material fluxes (cf. Dame et al. 1991). Thirdly, halophyte detritus may also leave the salt marsh as floating macromaterial. This may happen during storm events, but thin trails of debris leaving the marsh can also be seen during calm weather. Plant debris transported with the tides from Saeftinge can be found on many places along the estuarine dikes and salt marshes (Hemminga et al. 1990). The export of this macromaterial has not been quantified for the Saeftinge marsh, but studies in other salt marshes show that the export of macrodetritus represents only a small proportion of 
the annual primary production (Dame \& Stilwell 1984, Dankers et al. 1984).

With the provisos mentioned in the foregoing, our finding that inundation of Saeftinge had little or no impact on seston-POM characteristics most of the year can be taken as an indication that the Saeftinge salt marsh, large as it is, is an irrelevant factor in determining the nature of the POM in the Westerschelde estuary. Laane et al. (1987) used the caloric content of POM to assess its nutritive value to heterotrophic organisms. They concluded from a study of POM in the EmsDollard and Gironde estuaries, that variations in POM quality could be correlated with differences in biomass and production of macrobenthos. The present results make it unlikely that the functioning of pelagic and benthic foodwebs in the Westerschelde estuary will be influenced by effects of salt marsh inundation on seston-POM quality.

When we compare the present results with those obtained in Het Zwin (Hemminga et al. 1992), it is clear that inundation has different impacts on seston-POM characteristics in these marshes. In Het Zwin inundation resulted, throughout the year, in consistent shifts in biodegradability and chemical characteristics. Undoubtedly, one reason for the difference between Saeftinge and Het $\mathrm{Z}$ win is found in the contrasting hy drodynamic features of the tidal water body in these marshes. The tidal water flow in the only entrance channel of Het Zwin shows a strong asymmetry. Peak flow velocities are found during the flood tide. Furthermore, in contrast to the rapidly incoming flood tide, outflow of the water during ebb tide lasts much longer and coincides with slowly decreasing water levels (Van Kleef et al. 1989). These characteristics will allow sedimentation of particles from the water. This process probably is less pronounced in the tidal creek of Saeftinge that was sampled in this study, where peak flows are found at ebb tide, and the duration of flood and ebb tides is approximately equal. Likewise, resuspension of biotic and abiotic particles from the marsh surface may differ between the marshes, depending on the local hydrodynamic processes, and on sediment characteristics and group-specific attachment of benthic microbial organisms (De Jonge 1985). Finally, clear differences exist in the chemical characteristics of estuarine seston particles as the influence of the sea increases towards the mouth of the estuary (e.g. Eisma et al. 1985, Laane et al. 1987, Saliot et al. 1988, Schoer 1990). We may speculate that these differences coincide with differences in the physical characteristics of the seston-POM particles in seawater and in estuarine water, e.g. with respect to sedimentation and adhesion, and thus contribute to the discrepancy in tidal exchange characteristics between Het Zwin and Saeftinge.
Acknowledgements. The authors thank N. K. Goossen and P. van Rijswijk for isolation of the estuarine bacterial species, P. M. J. Herman for statistical advice, and A. A. Bolsius for drawing the map of Saeftinge.

\section{LITERATURE CITED}

Beeftink, W. G. (1977). The coastal salt marshes of western and northern Europe: an ecological and phytosociological approach. In: Chapman, V. J. (ed.) Wet coastal ecosystems. Elsevier, Amsterdam, p. 109-155

Boers, P. C. M., Boon, J. J. (1988). Unmasking the particulate organic matter in a lake ecosystem: origin and fate of POM in the shallow eutrophic Loosdrecht Lakes (The Netherlands). Arch. Hydrobiol. Beih. Ergebn. Limnol 31: $27-34$

Boon, J. J. (1989). An introduction to pyrolysis mass spectrometry of lignocellulosic material: case studies on barley straw, corn stem and Agropyron. In: Chesson, A., Orskov, E. R. (eds.) Physico-chemical characterisation of plant residues for industrial and feed use. Elsevier, Amsterdam, p. $25-50$

Chalmers, A. G., Wiegert, R. G., Wolf, P. L. (1985). Carbon balance in a salt marsh: interactions of diffusive export, tidal deposition and rainfall-caused erosion. Estuar. coast. Shelf Sci. 21: $757-771$

Cranford, P. J., Schwinghamer, P., Gordon, D. C. (1987). Identification of microdetritus derived from Spartina and its occurrence in the water column and intertidal sediments of Cumberland Basin, Bay of Fundy. Estuaries 10: $108-117$

Dame, R. F., Spurrier, J D., Williams, T. M, Kjerfve, B., Zingmark, R. G., Wolaver, T G., Chrzanowski, T H., McKellar, H. N., Vernberg, F. J. (1991). Annual material processing by a salt marsh-estuarine basin in South Carolina, USA. Mar. Ecol. Prog. Ser. 72: 153-166

Dame, R. F., Stilwell, D. (1984). Environmental factors influencing macrodetritus flux in North Inlet estuary. Estuar. coast. Shelf Sci. 18: 721-726

Dankers, N., Binsbergen, M., Zegers, K., Laane, R., Van Der Loeff, M. R. (1984). Transportation of water, particulate and dissolved organic and inorganic matter between a salt marsh and the Ems-Dollard estuary. The Netherlands. Estuar. coast. Shelf Sci. 19: 143-165

D'Avanzo, C. D., Valiela, I. (1990). Use of detrital foods and assimilation of nitrogen by coastal detritivores. Estuaries 13: $20-24$

Deegan, L. A., Peterson, B. J., Portier, R. (1990). Stable isotopes and cellulase activity as evidence for detritus as a food source for juvenile Gulf menhaden. Estuaries: 13: $14-19$

De Jonge, V. N. (1980). Fluctuations in the organic carbon to chorophyll a ratios for estuarine benthic diatom populations. Mar. Ecol. Prog. Ser. 2: 345-353

De Jonge, V. N. (1985). The occurrence of 'epipsammic' diatom populations: a result of interactions between physical sorting of sediment and certain properties of diatom species. Estuar. Coast. Shelf Sci. 21: 607-622

Eisma, D., Bernard, P., Boon, J. J., Van Grieken, R., Kalf, J., Mook, W. G. (1985). Loss of particulate organic matter in estuaries as exemplified by the Ems and Gironde estuaries. Mitt. geol.-paläont. Inst. Univ. Hamb. 58: $397-412$

Haines, E. B. (1976). Stable carbon isotope ratios in the biota, soils, and tidal water of a Georgia salt marsh. Estuar. coast. Mar. Sci. 4: 609-616 
Hargrave, B. T. (1972). Aerobic decomposition of sediment detritus as a function of particle surface area and organic content. Limnol. Oceanogr. 17: 583-596

Hargrave, B. T., Phillips, G. A. (1989). Decay times of organic carbon in sedimented detritus in a macrotidal estuary. Mar. Ecol. Prog. Ser. 56: 271-279

Hemminga, M. A., Van Soelen, J., Koutstaal, B. P. (1990). Tidal dispersal of salt marsh insect larvae within the Westerschelde estuary. Holarc. Ecol. 13: 308-315

Hemminga, M. A., Klap, V. A., Van Soelen, J., De Leeuw, J., Boon, J. J (1992). Shifts in seston characteristics after inundation of a European coastal salt marsh. Limnol. Oceanogr. 37(7): 1559-1564

Hewes, C. D., Sakshaug, E., Reid, F. M. H., Holm-Hansen, O. (1990). Microbial autotrophic and heterotrophic eucaryotes in Antarctic waters: relationships between biomass and chlorophyll, adenosine triphosphate and particulate organic carbon. Mar. Ecol. Prog. Ser. 63: 27-35.

Hoogerbrugge, R., Willig, S. J., Kistemaker, P. G. (1983). Discriminant analysis by double stage principal component analysis. Analyt. Chem. 55: 1710-1712

Hughes, E. H., Sherr, E. B. (1983). Subtidal food webs in a Georgia estuary: $\delta^{13} \mathrm{C}$ analysis. J. exp. Mar. Biol. Ecol. 67: $227-242$

Kreeger, D. A., Langdon, C. J., Newell, R. I. E. (1988) Utilization of refractory cellulosic carbon derived from Spartina alterniflora by the ribbed mussel Geukensia demissa. Mar. Ecol. Prog. Ser. 42: 171-179

Laane, R. W. P. M., Etcheber, H., Relexans, J. C. (1987). Particulate organic matter in estuaries and its ecological implication for macrobenthos. Mitt. geol.-paläont. Inst. Univ. Hamb. 64: 71-91

Newell, R. I. E., Langdon, C. J. (1986). Digestion and absorption of refractory carbon from the plant Spartina alterni flora by the oyster Crassostrea virginica. Mar. Ecol. Prog Ser. 34: 105-115

Odum, E. P., de la Cruz, A. (1967). Particulate organic detritus in a Georgia salt marsh-estuarine ecosystem. In: Lauff, G. H. (ed.) Estuaries; Am. Ass. Adv. Sci., Washington, DC, p 383-388

Peterson, B. J., Howarth, R. W. (1987). Sulfur, carbon, and nitrogen isotopes used to trace organic matter flow in the

This article was submitted to the editor salt-marsh estuaries of Sapelo Island, Georgia. Limnol Oceanogr. 32: 1195-1213

Peterson, B. J., Howarth, R. W., Garritt, R. H. (1986). Sulfur and carbon isotopes as tracers of salt-marsh organic matter flow. Ecology 67: 865-874

Roman, C. T., Daiber, F. C. (1989). Organic carbon flux through a Delaware Bay salt marsh: tidal exchange, particle size distribution, and storms. Mar. Ecol. Prog. Ser. 54: $149-156$

Saliot, A., Tronczynski, J., Scribe, P., Letolle, R. (1988). The application of isotopic and biogeochemical markers to the study of the biogeochemistry of organic matter in a macrotidal estuary, the Loire, France. Estuar. coast. Shelf Sci. 27 645-669

Schoer, J. H. (1990). Determination of the origin of suspended matter and sediments in the Elbe estuary using natural tracers. Estuaries 13: 161-172

Stuart, V., Head, E. J. H., Mann, K. H. (1985). Seasonal changes in the digestive enzyme levels of the amphipod Corophium volutator (Pallas) in relation to diet. J. exp. mar. Biol. Ecol. 88: 243-256

Sullivan, M. J., Moncreiff, C. A. (1990). Edaphic algae are an important component of salt marsh food-webs: evidence from multiple stable isotope analyses. Mar. Ecol. Prog. Ser. 62: $149-159$

Teal J. M. (1962). Energy flow in the salt marsh ecosystem of Georgia. Ecology 43: 614-624

Van Es, F. B., Laane, R. W. P. M. (1982). The utility of organic matter in the Ems-Dollard estuary. Neth. J. Sea Res. 16: $300-314$

Van Kleef, A. W., Lambeek, J. J. P., Masselink, G., Ruwe, J. P. A. (1989). Getijdeprocessen in het Zwin, Zeeuws Vlaanderen. Rapport GEOPRO 1989.03, Institute of Geographical Research, State University Utrecht

Windig, W., Haverkamp, J., Kistemaker, P. G. (1983). Interpretation of sets of pyrolysis mass spectra by discriminant analysis and graphical rotation. Analyt. Chem. 55: $81-88$

Wolaver, T. G., Spurrier, J. D. (1988). Carbon transport between a euhaline vegetated marsh in South Carolina and the adjacent creek: contributions via tidal inundation, runoff and seepage. Mar. Ecol. Prog. Ser. 42: 53-62

Manuscript first received: November 23, 1992

Revised version accepted: April 28, 1993 